\title{
50. DATA REPORT: STABLE CARBON AND OXYGEN ISOTOPIC COMPOSITION OF RHAETIAN SHELF CARBONATES, WOMBAT PLATEAU, NORTHWEST AUSTRALIA ${ }^{1}$
}

\author{
Massimo Sarti² and Otto Kälin²
}

\begin{abstract}
Stable oxygen- and carbon-isotope ratios of Rhaetian (upper Triassic) limestone samples from the Wombat Plateau, northwest Australia, were measured to explore possible diagenetic pathways that the material underwent after deposition in a shallow-water environment, before plateau submergence in the Early Cretaceous. Host sediment isotopic values cluster near typical marine carbonate values $\left(\delta^{18} \mathrm{O}\right.$ ranging from $-2.57 \%$ to $+1.78 \leqslant$ and $\delta^{13} \mathrm{C}$, from $+2.45 \%$ o to $+4.01 \%$ o). Isotopic values of equant clear calcite lining or filling rock pores also plot in the field of marine cements $\left(\delta^{18} \mathrm{O}=+1.59 \%\right.$ to $-2.24 \%$ and $\delta^{13} \mathrm{C}=+4.25 \%$ to $+2.57 \%$ ) , while isotopic values for neomorphic calcites replacing skeletal (megalodontid shell) carbonate material show a wider scatter of oxygen and carbon values, $\delta^{18} \mathrm{O}$ ranging from $+2.73 \%$ to $-6.2 \%$ and $\delta^{13} \mathrm{C}$, from $+5.04 \%$ o to $+1.22 \%$.

Selective dissolution of metastable carbonate phases (aragonite?) and neomorphic replacement of skeletal material probably occurred in a meteoric phreatic environment, although replacement products (inclusion-rich microspar, clear neomorphic spar, etc.) retained the original marine isotopic signature because transformation probably occurred in a closed system dominated by the composition of the dissolving phases (high rock/water ratio). The precipitation of late-stage equant (low-Mg?) calcite cement in the pores occurred in the presence of normal marine waters, probably in a deep-water environment, after plateau drowning.

Covariance of $\delta^{18} \mathrm{O}$ and $\delta^{13} \mathrm{C}$ toward negative values indeed suggests influence of meteorically modified fluids. However, none of the samples shows negative carbon values, excluding the persistence of organic-rich soils on subaerial karstic surfaces (Caribbean-style diagenesis). Petrographical and geochemical data are consistent with the sedimentological evidence of plateau drowning in post-Rhaetian times and with a submarine origin of the $>70$-m.y.-long Jurassic hiatus.
\end{abstract}

\section{INTRODUCTION}

In this paper we report some preliminary results on stable oxygen and carbon isotopic composition of Rhaetian (upper Triassic) shallow-water limestones drilled on the Wombat Plateau during Ocean Drilling Program (ODP) Leg 122 (Sites 761 and 764). A detailed account of microfacies and diagenetic textures of these rock types and their environmental interpretations is given by Röhl et al. (this volume). We here provide some additional data on the oxygen and carbon isotopic composition of some carbonate components, which furnish supplemental information on the diagenetic history and chem$\mathrm{ical} /$ mineralogical modification in the burial stage. These data might help in delineating possible scenarios for the sedimentary and structural history of the region.

\section{GEOLOGIC SETTING AND STRATIGRAPHIC OVERVIEW}

The Wombat Plateau is an isolated, tilted block of continental crust at the northern edge of Exmouth Plateau, off northwest Australia (Fig. 1), covered by upper Triassic clastics and shelfal carbonates (Leg 122 Shipboard Scientific Party, 1988; Haq, von Rad, O'Connell, et al., 1990; Borella et al., this volume). The plateau sediment cover wedges out southward and is truncated at the southern uplifted side. The Rhaetian (uppermost Triassic) carbonates are 160-240 m thick and consist of shallow-water platform-interior limestones (Site 761), changing into a pinnaclereef complex along the bank margin at Site 764 (Williamson et

\footnotetext{
1 von Rad, U., Haq, B. U., et al., 1992. Proc. ODP, Sci. Results, 122: College Station, TX (Ocean Drilling Program).

${ }^{2}$ Dipartimento di Scienze della Terra, Universita della Calabria, Arcavacata, Cosenza, Italy.
}

al., 1989). The carbonate package conformably rests on Norian clastic sediments and is subdivided into five distinctive intervals, correlatable between the two sites (Figs. 2 and 3). These intervals are, from bottom to top:

1. A 30-m-thick unit of thick-bedded, redeposited bioclastic limestone, quartzose sandstone mixed with skeletal components, and dark gray shale, containing abundant crinoid debris, scattered solitary corals, and mollusc fragments. At Site $764,9.6 \mathrm{~m}$ of crinoid-bearing, dark gray shale probably belonging to the same unit was recovered.

2. A red sponge and tabulozoan/hydrozoan boundstone, with a sharp lower contact. This distinctive interval is only $\mathbf{0 . 6}$ $\mathrm{m}$ thick at Site 761 but exceeds $40 \mathrm{~m}$ at Site 764. It consists of a biogenic rudstone, locally colonized by a micro-reef-building community dominated by calcareous sponges (Sarti et al., this volume). Red dolomitic interstitial material, rich in ironbearing minerals, is present. Solution cavities in partially leached aragonitic skeletons are lined or filled by coarse scalenohedral ("dogtooth") calcite (Fig. 4).

3. A unit of rhythmically alternating marl and bioturbated marly limestone, overlain by (Site 761) or interbedded with (Site 764) lighter colored skeletal limestone.

4. A package of white to light gray limestone (skeletal wackestone), irregularly interbedded with some algal-laminated limestone and/or dolomite, locally with a reddish stain (Site 761), and whitish coral boundstone, with different types of interstice-filling biocalcarenite and skeletal wackestone (Site 764). These limestones contain scattered shells of Megalodon showing different states of preservation and sedimentary infill (Fig. 5). Core recovery in this interval was minimal $(<8 \%)$. However, the wire-line log suggests that the whole unit consists of a massive package of limestone $73 \mathrm{~m}$ thick at Site 761 and slightly over $120 \mathrm{~m}$ at Site 764 . 


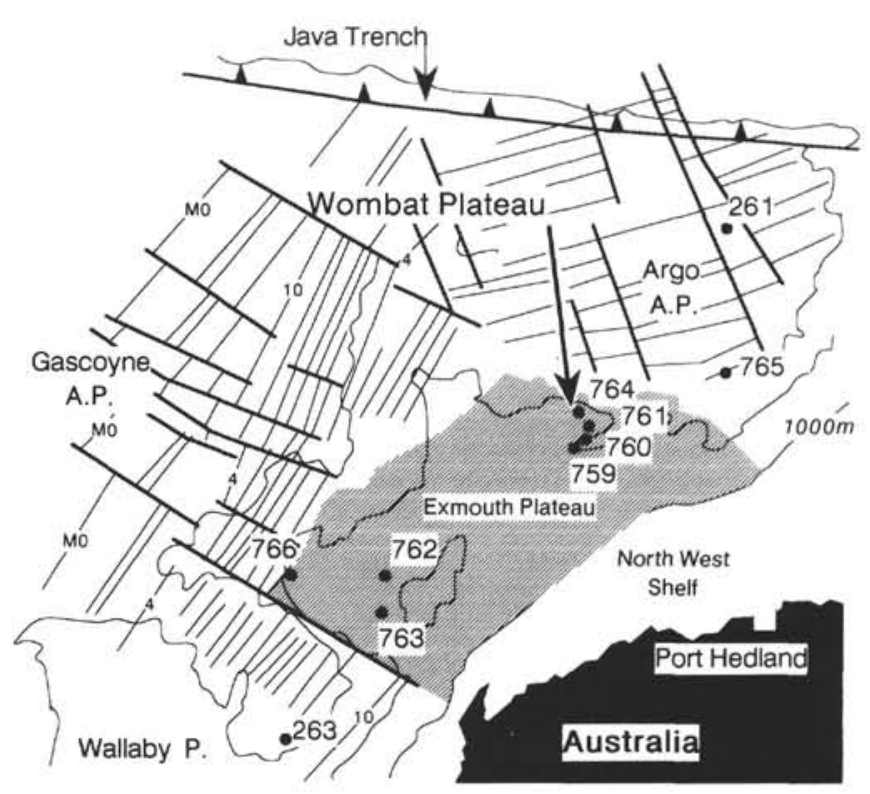

Figure 1. Physiographic-structural map of the northeast Indian Ocean and general location map of the Exmouth Plateau and Argo Abyssal Plain, off the Northwest Shelf of Australia. Thick and thin lines represent transform faults and magnetic-anomaly patterns, respectively. DSDP sites and ODP Leg 122 sites are shown.

5. A 20-m-thick interval of cyclically alternating, dark gray-yellowish marl and bioturbated marly limestone, containing calcareous nannofossils, benthic foraminifers, and sponge spicules. At Site 761 this unit was not sampled, but indirect evidence for its presence comes from a distinctive high gamma-ray excursion recorded in the wire-line log, above the carbonate interval (Interval 4). At Site 764, Interval 5 is overlain by a less than 8 -m-thick, Triasina-rich, slightly nodular crinoidal packstone to wackestone, with hematiterich, anastomosing microstylolite seams and localized bluish black stringers of manganese oxides.

The carbonate package ends with a hiatus encompassing most of the Jurassic and interpreted, according to different authors, as a consequence of sediment starvation and nondeposition in a submarine, pelagic environment (Sarti et al., this volume) or due to subaerial exposure of the plateau and erosion of younger (Jurassic) strata (von Rad et al., 1989). A relatively thin $(<300 \mathrm{~m})$ blanket of pelagic chalk and ooze drapes the unconformity.

\section{LABORATORY METHODS}

Stable-isotope ratio analyses were performed on calcium carbonate microsamples weighting from 0.5 to $1 \mathrm{mg}$, using a V.G. Isotech mass spectrometer, Prism Series II. The powders were soaked in $10 \%$ hydrogen peroxide to remove organic matter. Acetone was added to help drive off the organic matter and the peroxide. The excess solution was removed and the sample dried in the oven at $60^{\circ} \mathrm{C}$ for half an hour to $1 \mathrm{hr}$. The precision was calculated as $+0.06 \%$ o for oxygen and $+0.02 \%$ for carbon. Values are reported in the PDB standard notation.

\section{DESCRIPTION OF SAMPLES AND ANALYZED CARBONATE COMPONENTS}

Nine samples from distinctive lithologic types from the described units were examined. Their stratigraphic positions are indicated in Figures 2 and 3.
Sediment samples from the top of the carbonate package (Interval 4) at Hole 761B (Samples 122-761B-31X-CC, 0-1 cm; $122-761 \mathrm{~B}-31 \mathrm{X}-\mathrm{CC}, 8-10 \mathrm{~cm}$; and 122-761B-31X-CC, 15-17 $\mathrm{cm}$ ) consist of highly porous, fossiliferous/pelletal micrite (wackestone and packstone), locally rich in Triasina sp. and miliolids. Pores include roundish fenestrae (after gas-bubble or "bird's eye," Deelman, 1972) or vugs and biomolds, partially occluded by a thin fringe of "dogtooth" calcite cement (Pl. 1, Fig. 1).

Fragments of altered megalodontid shell are present in all samples. An inclusion-rich microspar layer, 0.5-2.5 up to 6-7 $\mathrm{mm}$ thick, is present along the periphery of the valve, with the crystal mosaic coarsening inward and turning into coarse (500-600 $\mu \mathrm{m})$ clear neomorphic calcite spar. The boundary between the inclusion-rich (cloudy) microspar layer and the clear neomorphic spar is sometimes abrupt and irregular, with dark inclusions clustered at crystal edges and forming a reticulate pattern (PI. 1, Figs. 3 and 4). In the clear calcite, relics of layered shell microstructure are common (Sample 122-761B-31X-CC, 15-17 cm) (PI. 1, Figs. 3 and 4), which in most cases are not recognizable within the inclusion-rich microspar rim.

Lamellae often reveal a fine prismatic structure on a section normal to the shell surface (Sample 122-761B-31X-CC, $15-17 \mathrm{~cm}$ ). In the central portion of a valve fragment, single large crystals of neomorphic calcite are composed of a number of radially arranged subcrystals, forming "rosettes" that are particularly evident in sections tangential to shell lamellae (Sample 122-761B-31X-CC, 8-10 cm).

The bulk sediment, the clear neomorphic spar with relics of lamellar microstructure, and the cloudy microspar along the periphery of the shell fragments were analyzed for stableisotope composition (Table 1).

The samples analyzed from the top of the carbonate package (Interval 4) at Hole 761C (Samples 122-761C-12R-1, 5-7 cm, and 122-761C-12R-1, 10-12 cm) closely resemble those from Hole $761 \mathrm{~B}$, both with respect to sediment types and preservation characteristics of the Megalodon shells, except for the presence of large cement-lined dissolution cavities within the skeletal fragments. In Sample 122-761C$12 \mathrm{R}-1,5-7 \mathrm{~cm}$, a large wedge-shaped cavity is lined by a fine-grained neomorphic mosaic grading into coarse-bladed to fibrous, cloudy calcite, with crystal fabric reminiscent of radiaxial fibrous cement (Pl. 1, Fig. 2). Euhedral crystal terminations are noticeable.

These cavity-filling or -lining cements, the bulk host-rock, and calcitized megalodontid shell material were selected for stable-isotope analyses (Table 1).

Three samples were selected from the lower part of the shallow-water-limestone unit (Interval 4) in Hole 761C (Samples 122-761C-20R-1, 8-10 cm, 122-761C-20R-1, 22-24 cm, and $122-761 \mathrm{C}-22 \mathrm{R}-1,5-7 \mathrm{~cm})$. All samples contain large megalodontid shell fragments showing a preservational style comparable to that of the previous specimens. The inclusion-rich microspar of the outer shell fragment shows crystal size increasing inward and has a fine network of sedimentfilled microborings in the outer $1 \mathrm{~mm}$ portion. Relics of growth layering of the shell are noticeable inward from the shell surface (Pl. 2, Fig. 1). Borings in the shell outer layer suggest a biogenic micritization, perhaps by boring fungi or algae.

Inclusions within the clear neomorphic spar, in the inner portion of the megalodontid shells, define a reticulate pattern of a rather uniform mesh size $(400-600 \mu \mathrm{m})$ (Pl. 2, Fig. 2), reminiscent of the alveolar shell structure described in rudists (Al-Aasm and Veizer, 1986a; 1986b). This alveolar shell structure is not described in megalodontids, so that inclusion 


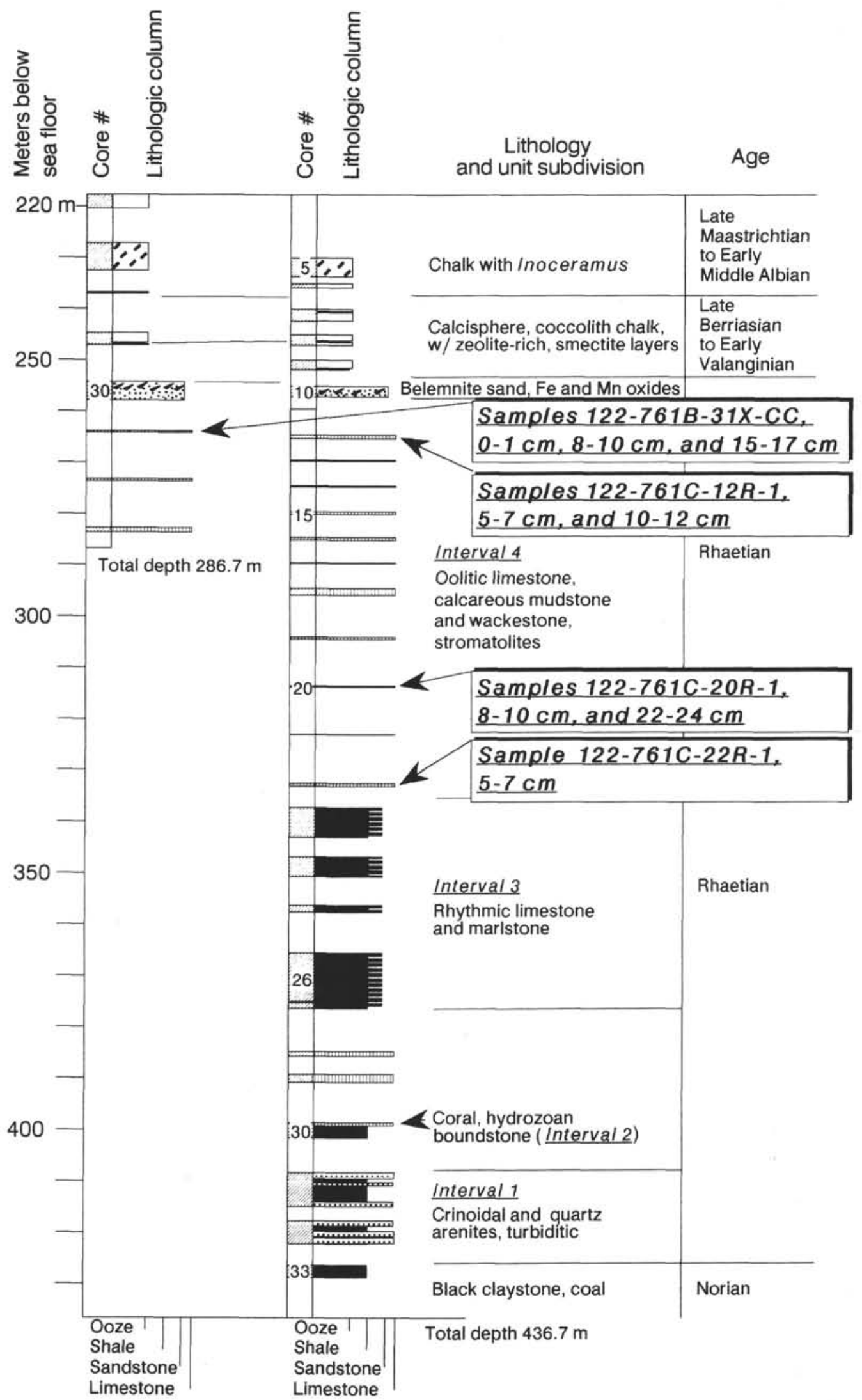

Figure 2. Lithologic column, Site 761, showing locations of the samples analyzed for stable-isotope composition. Major lithologic types and units referred to in the text are indicated. 


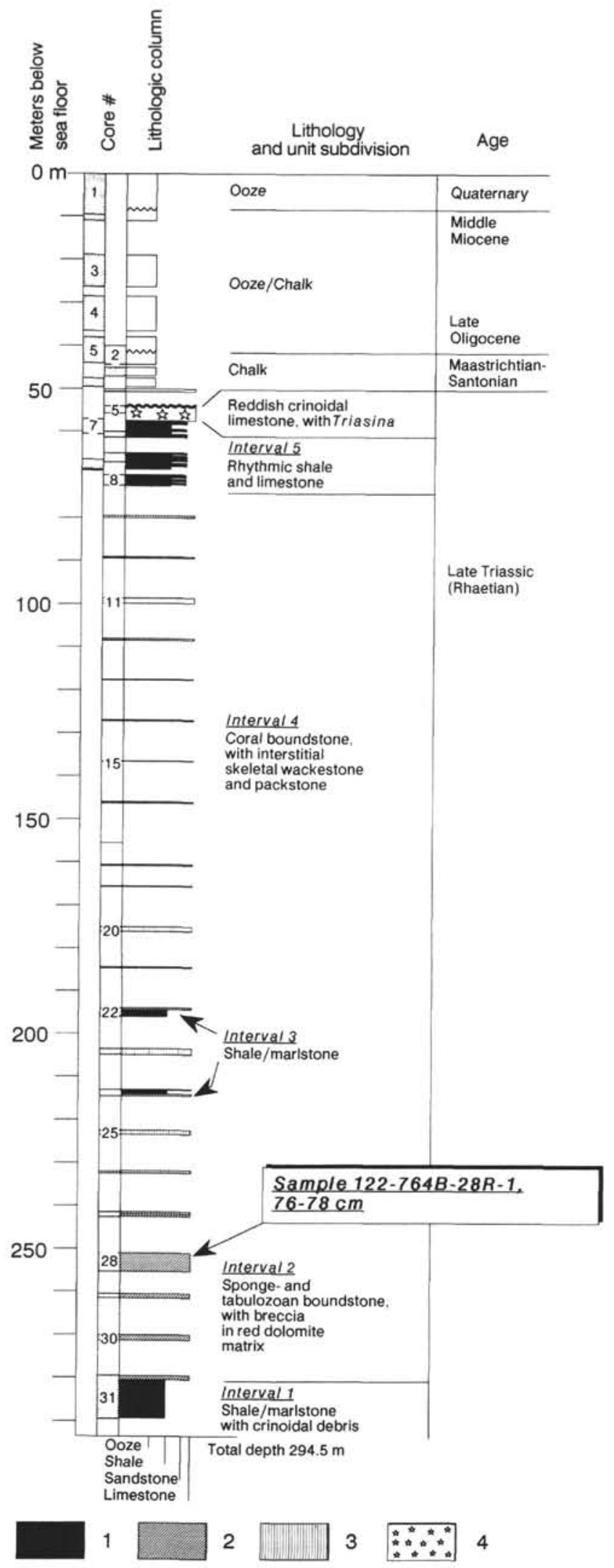

Figure 3. Lithologic column, Site 764 , showing locations of the samples analyzed for stable-isotope composition. Major lithologic types and units referred to in the text are indicated. $1=$ marl $/$ shale; 2 = sponge/tabulozoan boundstone; $3=$ coral boundstone; $4=$ crinoidal limestone.

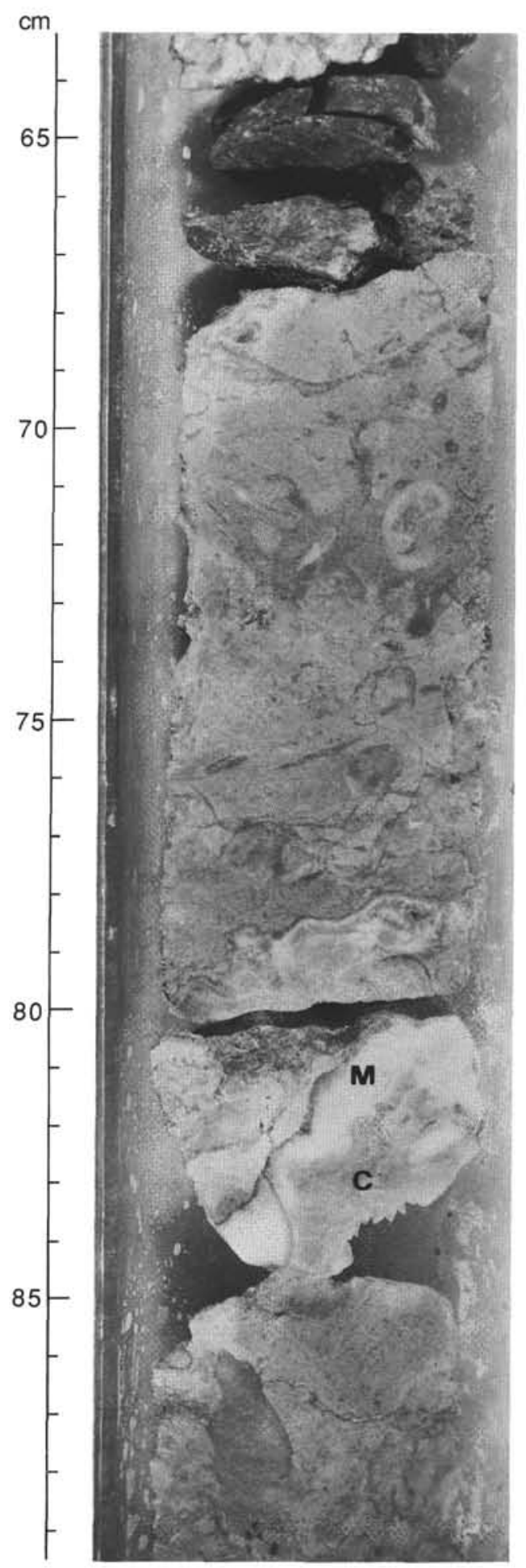

Figure 4. At interval 122-764B-28R-1, 79-85 cm, a skeletal fragment of Megalodon is seen, with a thick, whitish layer of neomorphic cloudy microspar (m) grading inward into clear neomorphic spar and calcite cement (c). Scalenohedral crystal terminations are seen at the lower right side of the block, at $84-85 \mathrm{~cm}$. The globose shape of the cavity at $80-84 \mathrm{~cm}$ suggests some dissolution of the shell interior and partial cement fill. At $78-80 \mathrm{~cm}$ (corresponding to the interval $76-78$ $\mathrm{cm}$ of the sampled piece in the working half of the core) is a dissolution cavity with traces of a bryozoan colony encrusting a shell substrate. The host rock is a pink microcrystalline dolomite hosting sponge and tabulozoan/hydrozoan colonies (boundstone). 


\section{A}

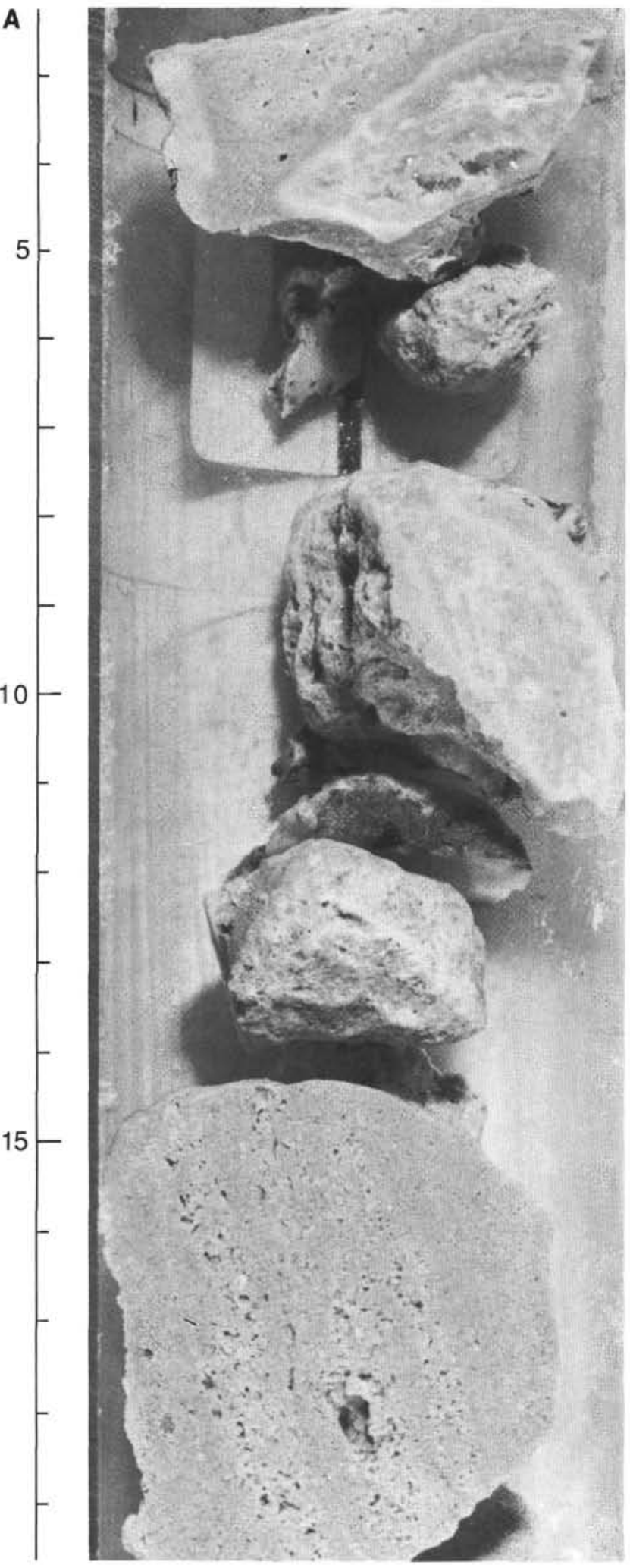

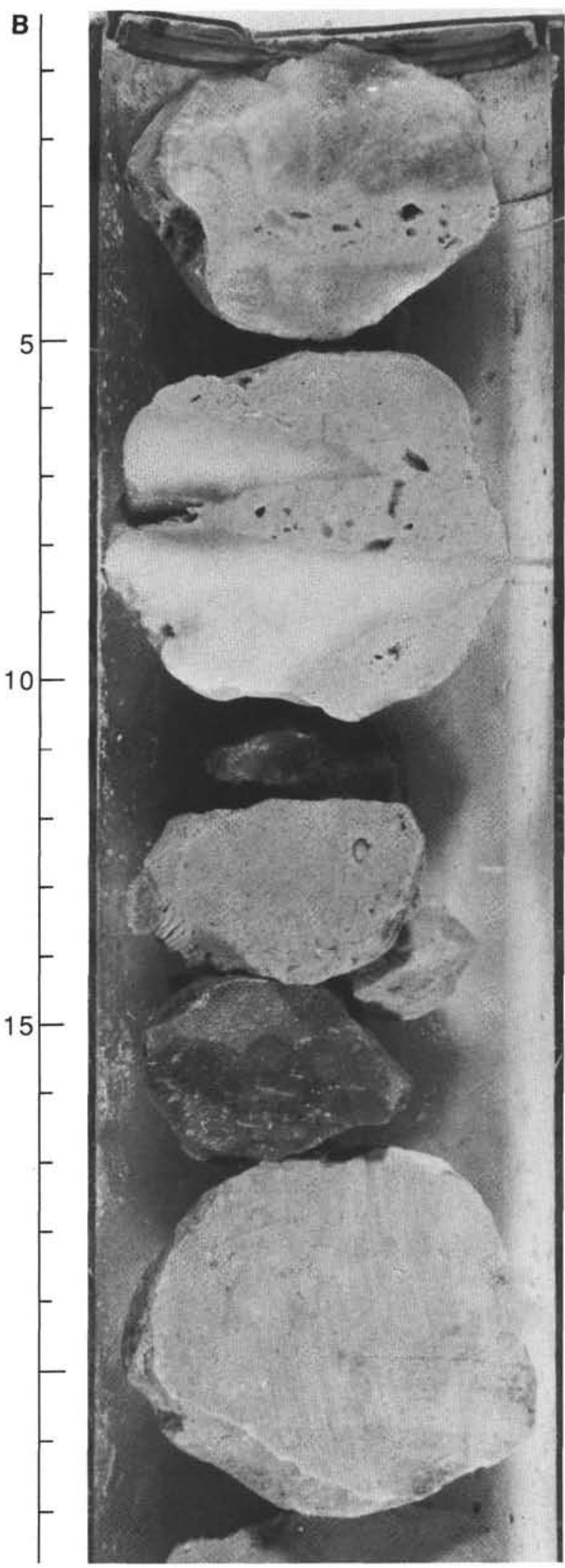

Figure 5. A. Sample 122-761C-12R-1, 8-11 cm, is part of a thick fragment of a Megalodon? shell (sampled at interval 122-761C-12R-1, 10-12 $\mathrm{cm}$, in the working half of the core), embedded in skeletal and pelletal packstone. Another fragment is Sample 122-761C-12R-1, 2-5 cm, (corresponding to the sampled interval $122-761 \mathrm{C}-12 \mathrm{R}-1,5-7 \mathrm{~cm}$, in the working half of the core). At 14-20 cm, the typical host rock is a laminated beach calcarenite (largely skeletal) with fenestral porosity. B. Sample $122-761 \mathrm{C}-22 \mathrm{R}-1,5-11 \mathrm{~cm}$, from the working half of the core prior to the sampling shows still-connected Megalodon valves in a highly porous pelletal and skeletal packstone. 
Table 1. Stable-isotope composition of carbonate components of Rhaetian shallowwater limestone of the Wombat Plateau.

\begin{tabular}{|c|c|c|c|}
\hline $\begin{array}{l}\text { Core, section, } \\
\text { interval }(\mathrm{cm})\end{array}$ & $\begin{array}{l}\delta^{13} \mathrm{C} \\
(\%)\end{array}$ & $\begin{array}{l}\delta^{18} \mathrm{O} \\
(\% 0)\end{array}$ & Sediment description \\
\hline \multicolumn{4}{|l|}{$122-761 B-$} \\
\hline $31 \mathrm{X}-\mathrm{CC}, 0-1$ & 2.45 & -2.57 & Bulk host rock \\
\hline $31 \mathrm{X}-\mathrm{CC}, 0-1$ & 3.19 & -1.01 & Inclusion-rich neomorphic (micro)spar \\
\hline $31 \mathrm{X}-\mathrm{CC}, 0-1$ & 2.04 & -3.26 & Inclusion-rich neomorphic (micro)spar \\
\hline $31 \mathrm{X}-\mathrm{CC}, 0-1$ & 3.45 & -1.66 & Coarsely crystalline clear neomorphic spar \\
\hline $31 \mathrm{X}-\mathrm{CC}, 0-1$ & 3.33 & -1.45 & Coarsely crystalline clear neomorphic spar \\
\hline $31 \mathrm{X}-\mathrm{CC}, 8-10$ & 3.93 & 0.75 & Bulk host rock \\
\hline $31 \mathrm{X}-\mathrm{CC}, 8-10$ & 4.24 & 0.68 & Inclusion-rich neomorphic (micro)spar \\
\hline $31 \mathrm{X}-\mathrm{CC}, 8-10$ & 3.34 & -1.16 & Inclusion-rich neomorphic (micro)spar \\
\hline $31 \mathrm{X}-\mathrm{CC}, 8-10$ & 5.04 & -0.31 & $\begin{array}{l}\text { Coarsely crystalline clear neomorphic spar ("rosette" } \\
\text { structure) }\end{array}$ \\
\hline $31 \mathrm{X}-\mathrm{CC}, 8-10$ & 4.10 & -2.45 & Coarsely crystalline clear neomorphic spar \\
\hline $31 \mathrm{X}-\mathrm{CC}, 15-17$ & 3.77 & 0.22 & Bulk host rock \\
\hline $31 \mathrm{X}-\mathrm{CC}, 15-17$ & 3.64 & -0.83 & Inclusion-rich neomorphic (micro)spar \\
\hline $31 \mathrm{X}-\mathrm{CC}, 15-17$ & 4.35 & 0.48 & Inclusion-rich neomorphic (micro)spar \\
\hline $31 \mathrm{X}-\mathrm{CC}, 15-17$ & 3.45 & -3.47 & Coarsely crystalline clear neomorphic spar \\
\hline $31 \times-C C, 15-17$ & 4.07 & -1.95 & Coarsely crystalline clear neomorphic spar \\
\hline \multicolumn{4}{|l|}{$122-761 C-$} \\
\hline $12 \mathrm{R}-1,5-7$ & 4.00 & 1.30 & Bulk host rock \\
\hline $12 \mathrm{R}-1,5-7$ & 4.25 & 1.59 & Cloudy/clear, bladed calcite cement (?radiaxial-fibrous) \\
\hline $12 \mathrm{R}-1,10-12$ & 4.91 & 2.73 & Inclusion-rich neomorphic (micro)spar \\
\hline $12 \mathrm{R}-1,10-12$ & 1.22 & -6.17 & Coarsely crystalline clear neomorphic spar \\
\hline $20 \mathrm{R}-1,8-10$ & 3.65 & 0.49 & Bulk host rock \\
\hline $20 \mathrm{R}-1,8-10$ & 4.34 & 1.76 & Inclusion-rich neomorphic (micro)spar \\
\hline $20 \mathrm{R}-1,8-10$ & 4.59 & 0.77 & Coarsely cryst. neomorphic spar, inclusion-rich \\
\hline $20 \mathrm{R}-1,8-10$ & 3.96 & -0.52 & Transition between microspar-coarse spar \\
\hline $20 \mathrm{R}-1,22-24$ & 4.01 & 1.78 & Bulk host rock \\
\hline $20 \mathrm{R}-1,22-24$ & 4.20 & 1.52 & Inclusion-rich neomorphic (micro)spar \\
\hline $20 \mathrm{R}-1,22-24$ & 3.23 & -0.63 & Inclusion-rich neomorphic (micro)spar \\
\hline $20 \mathrm{R}-1,22-24$ & 3.91 & -1.82 & Coarsely crystalline neomorphic spar, inclusion-rich \\
\hline $20 \mathrm{R}-1,22-24$ & 4.85 & 0.92 & Coarsely crystalline neomorphic spar. inclusion-rich \\
\hline $22 \mathrm{R}-1,5-7$ & 3.66 & 0.27 & Microspar, ghosts of shell growth layers \\
\hline $22 \mathrm{R}-1,5-7$ & 3.42 & -0.99 & Prismatic outer shell layer \\
\hline \multicolumn{4}{|l|}{$122-764 \mathrm{~B}-$} \\
\hline 28R-1, 76-78 & 3.50 & 0.31 & Bulk host rock \\
\hline $28 \mathrm{R}-1,76-78$ & 3.74 & 1.60 & Microspar (Megalodon shell wall) \\
\hline $28 \mathrm{R}-1,76-78$ & 2.56 & -1.29 & $\begin{array}{l}\text { Bryozoan-bored Megalodon shell wall (including } \\
\text { sediment) }\end{array}$ \\
\hline 28R-1, 76-78 & 2.57 & -2.17 & Coarsely crystalline clear blocky calcite cement \\
\hline $28 \mathrm{R}-1,76-78$ & 2.95 & -2.24 & Clear blocky calcite (solution-cavity fill of Megalodon) \\
\hline
\end{tabular}

For discussion, see text.

bands might alternatively represent growth stages of zoned crystals, i.e., a purely neomorphic fabric, independent from the nature and structure of the precursor. Their origin remains unclear.

In Sample 122-761C-22R-1, 5-7 cm, the Megalodon shell fragment has remnants of a neomorphically replaced prismatic layer on the outside of the lamellar unit (Pl. 2, Fig. 3). A system of partially cement-filled cavities is present within the inner portion of some shells, possibly resulting from selective dissolution of the inner shell layer.

The host rock, the inclusion-rich neomorphic microspar of the shell peripheral rim, the coarsely crystalline neomorphic mosaic with zoned crystals, and the transition zone between these two latter intervals were analyzed for stable-isotope composition. One microsample was taken from the outer prismatic shell layer.

One sample $(122-764 \mathrm{~B}-28 \mathrm{R}-1,76-78 \mathrm{~cm})$ comes from the red, dolomitic sponge and tabulozoan/hydrozoan boundstone at Hole 764B. This interval, which includes zones with biogenic elements embedded in bright-red fossiliferous dolomite (float- or rudstone, Fig. 4), had a controversial interpretation as a submarine condensed interval (Sarti et al., this volume) or a subaerial exposure horizon (Röhl et al., this volume). Marine isotopic values and positive $\delta^{13} \mathrm{C}$ measured are consistent with the presence of marine biota in this interval, and therefore its interpretation as a sedimentstarved biogenic unit is preferred.

Sample 122-764B-28R-1, 76-78 cm, shows traces of a bryozoan colony encrusting megalodontid shell rubble. The bryozoan colony is represented by a spiral-shaped microboring network or borings filled by micritic host sediment, and is "rooted" on a inclusion-rich microspar substrate. The boundary with the inner blocky calcite cement (solution-cavity fill of the megalodontid shell) is rather abrupt (PI. 2, Fig. 4). The host rock is an iron oxide-rich microcrystalline dolomite with fragments of bryozoan colonies, brachiopod shells, and crinoid ossicles.

Microspar rimming the megalodontid shell fragment, microspar including microboring sediment fill, the clear blocky calcite cement (megalodontid mold fill), and the host sediment were analyzed for stable-isotope composition.

\section{STABLE ISOTOPE DATA}

Carbon and oxygen isotopic compositions of the carbonate components described in the preceding section were measured to explore different hypotheses on the depositional and 
diagenetic environments and evaluate the possibility of postdepositional modification of the sediments in a meteoric setting. Measured stable-isotope ratios from three basic carbonate components-(1) shallow-marine sediment; (2) "dogtooth" and equant calcite cement, both cloudy and inclusionfree; and (3) neomorphic calcite replacing megalodontid skeletal material-are listed in Table 1 and plotted in Figure 6.

Isotopic values of the bulk calcareous sediment cluster near typical Holocene marine carbonate values (Hudson, 1977; Moore, 1989), with $\delta^{18} \mathrm{O}$ ranging from $-2.57 \%$ to $+1.78 \%$ (average $+0.33 \%$ ) and $\delta^{13} \mathrm{C}$ ranging from $+2.45 \%$ to $+4.00 \%$ (average $+3.63 \%$ ).

Calcite cements also show Holocene normal-marine values, plotting in the field of marine cements (Moore, 1989), although a difference in the oxygen value seems to be present at the two sites. At Site $761 \delta^{18} \mathrm{O}$ is $+1.59 \%$ and $\delta^{13} \mathrm{C}$ is $+4.25 \%$ while at Site 764 , the same equant calcite has slightly
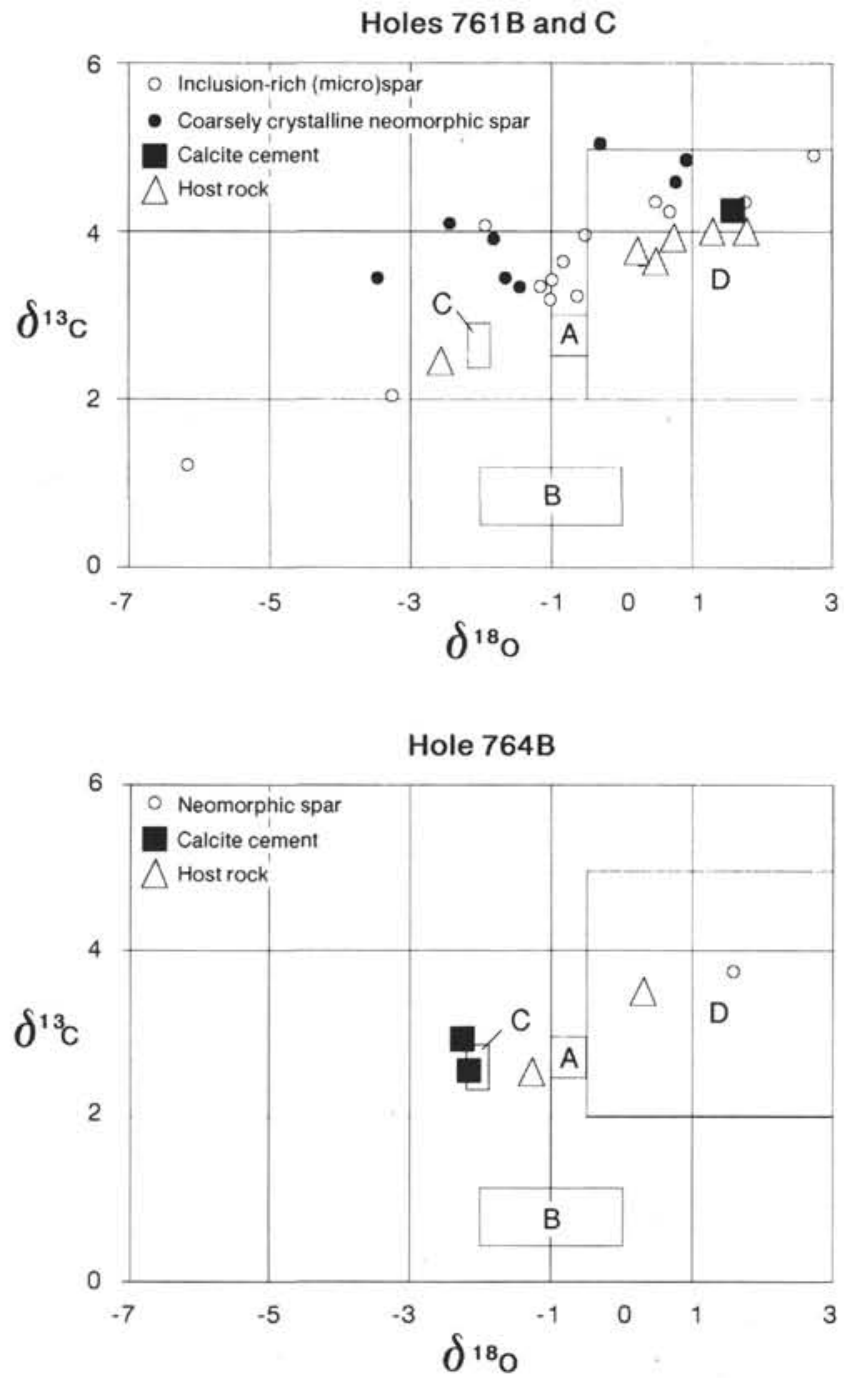

Figure 6. Stable carbon and oxygen composition of carbonates. Holes 761B, 761C, and 764B. A. Estimates of upper Triassic marine isotopic values from calcitic marine cements in low-latitude reefal sequences, after Lohmann (1987). B. Estimated isotopic composition of upper Triassic original marine carbonate, after Tucker and Wright (1990). C. Estimates of isotopic composition of upper Triassic marine waters, after Mazzullo et al. (1990). D. Field for shallow-marine carbonate cements and sediments, after Tucker and Wright (1990). negative oxygen values $\left(\delta^{18} \mathrm{O}\right.$, from $-2.24 \%$ to $-2.2 \%$ ), associated to positive $\delta^{13} \mathrm{C}$ of $+2.57 \%$ o to $+2.95 \%$.

Neomorphic calcites replacing megalodontid skeletal material show a wider scatter of oxygen and carbon values, $\delta^{18} \mathrm{O}$ ranging from $+2.73 \%$ to $-6.2 \%$ and $\delta^{13} \mathrm{C}$ ranging from $+5.04 \%$ to $+1.22 \%$.

\section{DISCUSSION}

From petrographic examination of the Rhaetian rock samples, it was observed that a common diagenetic feature of aragonitic skeletal (mainly mollusk) material is selective dissolution, which possibly occurred before early mechanical stabilization of the host sediment by intergranular cementation in the marine phreatic zone. Aragonite dissolution caused extensive biomoldic porosity in the sediment, which is associated with primary pores, such as fenestrae ("bird's eyes") or sheltered cavities.

Large megalodontid shell fragments are not completely removed by macroscale dissolution and are neomorphically altered to calcite by a process of "microscale dissolution" across a thin reaction film (Moore, 1989). These two processes coexist, and their relative importance varies greatly in each of our samples. However, no systematic depthwise trends were noted. Replacement products (microspar rim, coarsely crystalline calcite mosaic, etc.) are independent from the original shell microstructure but seem rather related to modes of neomorphic replacement. Growth layering in the inner shell often retains oriented relics of the original (aragonite?) microstructure (the 5-20 $\mu \mathrm{m}$ " palisade" crystal fabric). Preserved relics suggest the presence of "crossedlamellar" or "complex cross-lamellar" and "prismatic" microstructure probably associated with the myostracal shell layer.

Commonly, large parts of megalodontid fragments are selectively dissolved, with ample dissolution pores (as much as $2-3 \mathrm{~cm}$ wide, Fig. 4) formed at the expense of the inner shell. Some whole shells may have been removed by dissolution, leaving large casts in the sediments.

More or less isopachous fringes of bladed to scalenohedral "dogtooth" calcite cement, with or without a drusy fill of equant clear (low-Mg?) calcite spar, commonly line and fill pore space. In particular, thinner and more uniformly thick-bladed crusts prevail in primary intergranular pores, while "dogtooth" to blocky calcite characterizes molds and vugs.

In larger voids, mainly shelter pores and secondary dissolution cavities in Megalodon shells, the first cement is a more or less isopachous crust of bladed to fibrous, inclusion-rich spar resembling radiaxial fibrous calcite (Kendall, 1985). Microdolomite inclusions suggest an original high-Mg calcite precursor (Lohmann and Meyers, 1977). The single cement crystals are syntaxial with the underlying neomorphic calcite.

Selective dissolution of metastable carbonate phases (aragonite?) may occur both under meteoric and deep-marine conditions, where a range of pore fluids undersaturated with respect to aragonite are available. Neomorphism is considered to be a major diagenetic process in shallow-meteoric environments (Longmar, 1980; Pingitore, 1976) or in deep-marine burial settings (Sandberg and Hudson, 1983) and is not environment-specific. Precipitation of "dogtooth" and equant low- $\mathrm{Mg}$ calcite cement has been associated with freshwater pore fluids (Folk, 1974) from the meteoric-phreatic environment to the deep-marine environment (Schlager and James, 1978; Given and Wilkinson, 1985) or to shallow burial conditions, in the presence of low $\mathrm{CO}_{3}$ - concentrations (Moore, 1989). The carbonate phases alone observed at Sites 761 and 764 are not incompatible with any of the mechanisms of 
formations discussed, and available data do not suggest any unique explanation. The model we envisaged, following Moldovanyi and Lohmann (1984) and Freeman-Lynde et al. (1986), invokes repeated episodes of meteoric diagenesis, causing dissolution of metastable carbonate phases, and resubmergence in a marine diagenetic environment (Fig. 7). Early dissolution of metastable carbonate phases by meteoric or meteorically modified marine fluids depended upon the setup of a semipermanent freshwater lens on the platform top. Resubmergence caused precipitation of second-generation radiaxial fibrous calcites which, based on current interpretation, formed as primary precipitates in a marine phreatic diagenetic environment (Kendall, 1985).

The isotopic composition of cloudy cement at Site 761 is on an average heavier than that of the radiaxial fibrous calcites and cements described by Saller (1986), Mazzullo et al. (1990), Moldovanyi and Lohmann (1984), and Freeman-Lynde et al. (1986), and is within the average composition of marine cements and sediments (Tucker and Wright, 1990) (Fig. 6). This indeed suggests precipitation from marine pore fluids.

The clear calcite spar at Site 764 is probably the youngest cement of all and has oxygen isotopic values slightly lighter than those of the deep-water equant spar of Freeman-Lynde et al. (1986) but within the field of cogenetic marine waters for the upper Triassic estimated by Mazzullo et al. (1990) in a closely comparable setting. Its isotopic value is not incompatible with precipitation in a meteoric phreatic environment, although a deep-water origin cannot be ruled out. Geochemical and petrographic evidence is inconclusive.

The isotopic composition of the neomorphically replaced shell material has a spectrum of $\delta^{18} \mathrm{O}$ and $\delta^{13} \mathrm{C}$ values largely in the normal-marine field with a trend toward lighter $\delta^{18} \mathrm{O}$, possibly reflecting re-equilibration in a shallow-burial environment with increasing pore-water temperature. However, the modest overburden of plateau limestone $(50-250 \mathrm{~m}$ of sedi-

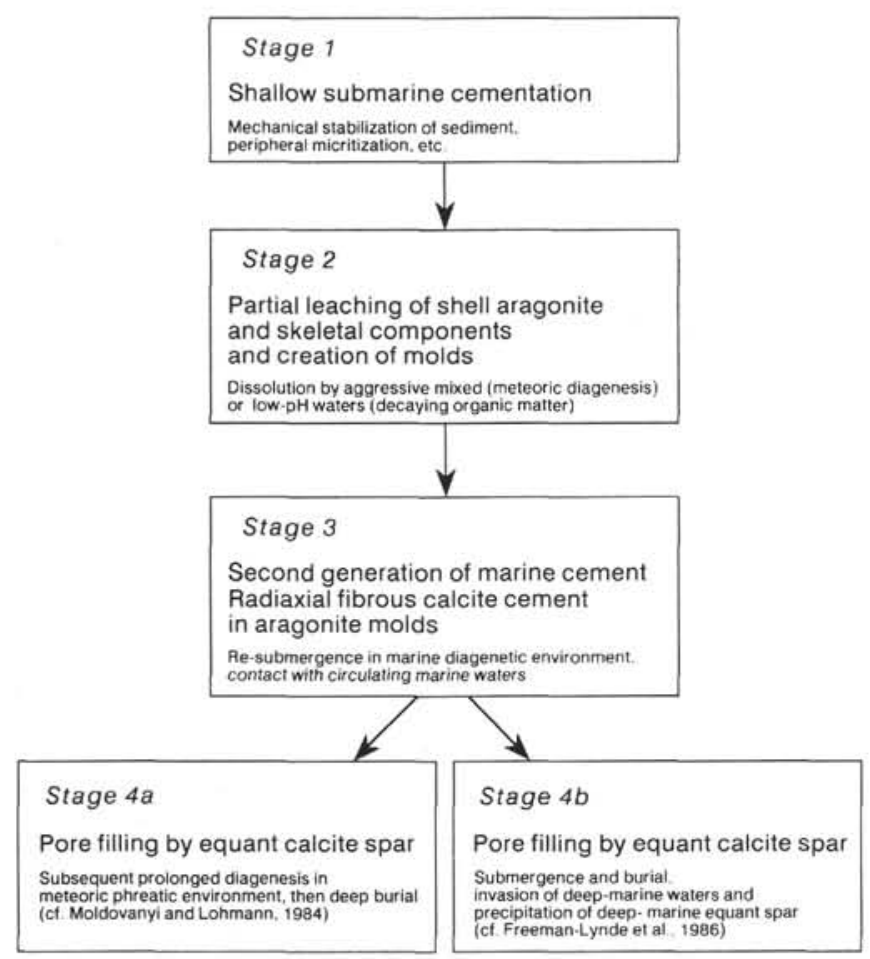

Figure 7. Diagram showing the major diagenetic pathways of Rhaetian carbonates at Sites 761 and 764 . ments in post-Triassic times) only partially accounts for the moderately negative $\delta^{18} \mathrm{O}$ values, which may exceed $-6 \%$. More likely, this is an effect of mixing with isotopically light meteoric fluids. A stable-isotope trend evident from the crossplot of Figure 6 is the covariance of $\delta^{18} \mathrm{O}$ and $\delta^{13} \mathrm{C}$ toward lower values. However, this does not show the typical meteoric-calcite excursion with invariant oxygen values and highly variable and negative carbon values (inverted "J," Lohmann, 1982 , 1987), which might point to stages of progressive diagenesis under meteoric-water conditions.

The marine signature of neomorphic calcites suggests re-equilibration in a rather closed system with respect to the oxygen and carbon, dominated by the isotopic composition of the dissolving metastable carbonate phase (high rock/water ratio).

Estimates of starting oxygen and carbon compositions (marine cogenetic signatures) of a suite of upper Triassic marine carbonates (Lohmann, 1987; Tucker and Wright, 1990; Mazzullo et al., 1990) (Fig. 6) show significantly lighter oxygen values than most of our samples. Enrichment in the heavier ${ }^{18} \mathrm{O}$ isotope detected in the majority of our carbonate components might alternatively suggest re-equilibration in deep-marine, cold-water settings (Mazzullo et al., 1990) or under evaporative conditions in an intertidal, platform interior environment. Geochemical evidence is again inconclusive.

\section{SUMMARY AND CONCLUSIONS}

1. All examined samples show the dissolution of metastable carbonate phases (aragonite?) and the neomorphic replacement of skeletal material that probably occurred in a meteoric phreatic environment.

2 . The marine isotopic signature of early cements indeed denotes precipitation from marine fluids, while retention of a marine isotopic composition in neomorphic calcites probably depends on re-equilibration in a closed, rock-dominated system (high rock/water ratio).

3. Equant (low-Mg?) calcite cements at Site 761 are enriched in the heavy ${ }^{18} \mathrm{O}$ isotope, hence the possibility of precipitation from deep-marine cold waters is not precluded.

4. All samples show identical diagenetic history, regardless of depth and location, with only a slight negative shift in the oxygen isotopic composition of cements in the deepest sample at Site 764. This suggests that basic diagenetic modification of original carbonate components occurred under the influence of a semipermanent freshwater lens, a common situation in carbonate platforms subject to a humid climate.

5. Covariance of $\delta^{18} \mathrm{O}$ and $\delta^{13} \mathrm{C}$, and ${ }^{18} \mathrm{O}$ excursion toward negative values of up to $-6 \%$ indeed suggest influence of meteoric or meteorically modified fluids. However, the typical meteoric-calcite excursion ("inverted J," Lohmann, 1982, 1987) with invariant oxygen values and highly variable and negative carbon values is not developed. None of the isotopic carbon data shows negative carbon values, excluding the persistence of organic-rich soils on subaerial karstic surfaces (Caribbean-style diagenesis). Petrographical and geochemical data are consistent with the sedimentological evidence of plateau drowning in post-Rhaetian times and with a submarine origin of the $>70-\mathrm{m}$.y.-long Jurassic hiatus.

\section{ACKNOWLEDGMENTS}

We are grateful to Ocean Drilling Program personnel, both shipboard and shore-based, for helpful assistance and to the SEDCO crew, whose competent contribution made the Exmouth Plateau cruise a success. We wish to thank J. Cartridge, Department of Earth Sciences, University of Oxford, U.K., for stable-isotope analyses and R. Brandoli, 
University of Ferrara, Italy, for photomicrographs. We are particularly indebted to U. von Rad and B. U. Haq for comments and to S. Bernasconi and D. Bernoulli, who reviewed the manuscript. Financial support for this study was provided by Consiglio Nazionale delle Ricerche, Rome (Grant no. 89.04752.CT05, M. Sarti) and by the North Atlantic Treaty Organization, Brussels (Grant no. 154/89, M. Sarti).

\section{REFERENCES}

Al-Aasm, I. S., and Veizer, J., 1986a. Diagenetic stabilization of aragonite and low-Mg Calcite, I. Trace elements in rudists. $J$. Sediment. Petrol., 56:138-152.

1986b. Diagenetic stabilization of aragonite and low-Mg Calcite, II. Stable isotopes in rudists. J. Sediment. Petrol., 56:763-770.

Deelman, J. C., 1972. On the mechanism causing birdseye structures. Neues Jahrb. Geol. Palaentol. Abh., 12:582-595.

Folk, R. L., 1974. The natural history of crystalline calcium carbonate: effects of magnesium content and salinity. J. Sediment. Petrol., 44:40-53.

Freeman-Lynde, R. P., Fulker Whitley, K., and Lohmann, K. C., 1986. Deep-marine origin of equant spar cements in Bahama Escarpment limestones. J. Sediment. Petrol., 56:799-811.

Given, R. K., and Wilkinson, B. H., 1985. Kinetic control of morphology, composition and mineralogy of abiotic sedimentary carbonates. J. Sediment. Petrol., 55:109-119.

Haq, B. U., von Rad, U., O'Connell, S., et al., 1990. Proc. ODP, Init. Repts., 122: College Station, TX (Ocean Drilling Program).

Haq, B., von Rad, U., and Shipboard Scientific Party, 1988. ODP Leg 122 looks at Exmouth Plateau. Geotimes, 33:10-13.

Hudson, J. D., 1977. Stable isotopes and limestone lithification. J. Geol. Soc. London, 133:637-660.

Kendall, A. C., 1985. Radiaxial fibrous calcite: a reappraisal. In Schneidermann, N., and Harris, P. H. (Eds.), Carbonate Cements. Spec. Publ.-Soc. Econ. Paleontol. Mineral., 36:59-77.

Lohmann, K. C., 1982. "Inverted J" carbon and oxygen isotopic trends: a criterion for shallow meteoric phreatic diagenesis. Geol. Soc. Am. Abstr. Programs, 14:548. (Abstract)

1987. Geochemical patterns of meteoric diagenetic systems and their applications to studies of paleokarst. In James, N. P., and Choquette, P. W. (Eds.), Paleokarst: New York (SpringerVerlag), 58-80.
Lohmann, K. C., and Meyers, W. J., 1977. Microdolomite inclusions in cloudy prismatic calcites: a proposed criterion for high-magnesium calcites. J. Sediment. Petrol., 47:1078-1088.

Longman, M. W., 1980. Carbonate diagenetic textures from nearshore diagenetic environments. AAPG Bull., 64:461-487.

Mazzullo, S. J., Bischoff, W. D., and Lobitzer, H., 1990. Diagenesis of radiaxial fibrous calcites in a subunconformity, shallow-burial setting: Upper Triassic and Liassic, Northern Calcareous Alps, Austria. Sedimentology, 37:407-425.

Moldovanyi, E. P., and Lohmann, K. C., 1984. Isotopic and petrographic record of phreatic diagenesis: Lower Cretaceous Sligo and Cupido Formations. J. Sediment. Petrol., 54:972-985.

Moore, C. H., 1989. Carbonate Diagenesis and Porosity: Amsterdam (Elsevier).

Pingitore, N. E., 1976. Vadose and phreatic diagenesis: processes, products, and their recognition in corals. J. Sediment. Petrol., 46:985-1006.

Saller, A. H., 1980. Radiaxial calcite in lower Miocene strata, subsurface Enewetak atoll. J. Sediment. Petrol., 56:743-762.

Sandberg, P. A., 1985. Aragonite cements and their occurrence in ancient limestones. In Schneidermann, N., and Harris, P. H. (Eds.), Carbonate Cements. Spec. Publ.-Soc. Econ. Paleontol. Mineral., 36:33-57.

Sandberg, P. A., and Hudson, J. D., 1983. Aragonite relic preservation in Jurassic calcite-replaced bivalves. Sedimentology, 30:879892.

Schlager, W., and James, N. P., 1978. Low-magnesian calcite limestones forming at the deep-sea floor, Tongue of the Ocean, Bahamas. Sedimentology, 25:675-702.

Tucker, M. E., and Wright, P. V., 1990. Carbonate Sedimentology: Oxford (Blackwell Sci. Publ.)

von Rad, U., Thurow, J., Haq, B. U., Gradstein, F., Ludden, J., and ODP Leg 122/123 Shipboard Scientific Parties, 1989. Triassic to Cenozoic evolution of the NW Australian continental margin and the birth of the Indian Ocean (preliminary results of ODP Legs 122 and 123). Geol. Rundsch., 78:1189-1210.

Williamson, P. E., Exon, N. F., Haq, B. U., von Rad, U., and Leg 122 Shipboard Scientific Party, 1989. A Northwest Shelf Triassic reef play: results from ODP Leg 122. APEA J., 29:328-344.

Date of initial receipt: 26 June 1990

Date of acceptance: 18 March 1991

Ms 122B-147 

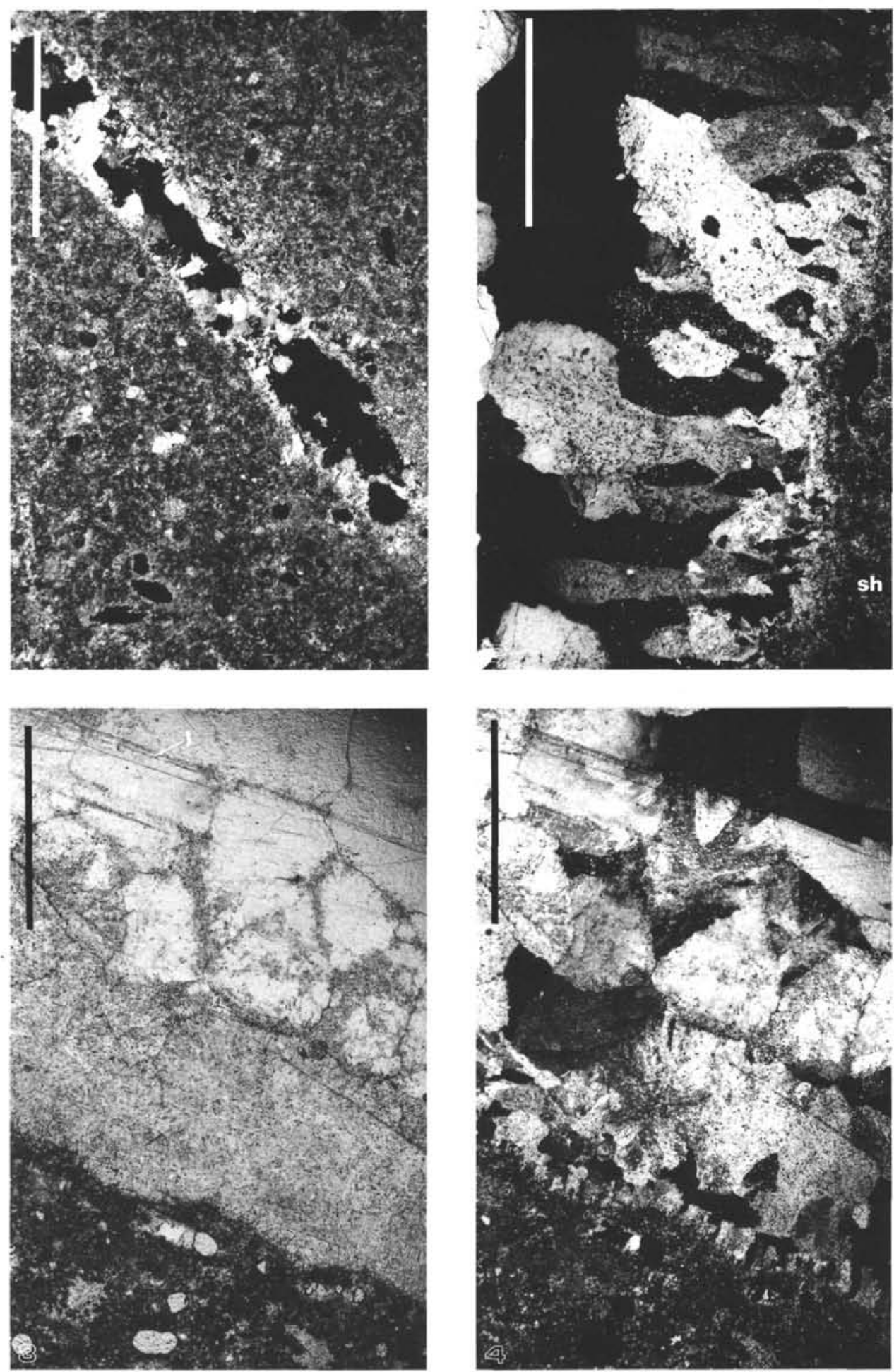

Plate 1. Microfacies and preservational features of megalodontid shells from the uppermost part of the Rhaetian shallow-water limestone unit, Holes 761B and 761C. 1. Pelletal micrite with elongate biomoldic cavity lined by a fringe of "dogtooth" cement. Small round pores in the host sediment may be in part primary ("bird's eyes," gas bubbles). Parallel nicols. Scale bar is $1 \mathrm{~mm}$ (Sample 122-761B-31X-CC, 8-10 cm). 2. Bladed to fibrous, inclusion-rich (cloudy) calcite cement partially occluding a dissolution cavity in a Megalodon shell fragment. Along the bioeroded shell surface (sh) and below the cement there is locally a thin layer of replacement microspar. Cement crystals show faintly undulose extinction, and inclusion density diminishes markedly in the lower portions of the crystals. Note relic void (black) in the center of the cavity (left). Crossed nicols. Scale bar is $1 \mathrm{~mm}$. Sample $122-761 \mathrm{C}-12 \mathrm{R}-1,5-7 \mathrm{~cm}$. 3, 4. Outer part of a Megalodon shell (above), in contact with the host sediment (below). A peripheral, millimeter-thick layer of cloudy neomorphic microspar is followed inward by clear neomorphic spar across a transition zone where dark, noncarbonate inclusions are concentrated along crystal peripheries, defining a reticulate pattern. Note relic preservation of growth layering of the shell (1). Scale bar is $1 \mathrm{~mm}$. Sample 122-761B-31X-CC, 15-17 cm. 3. Parallel nicols. 4. Crossed nicols. 

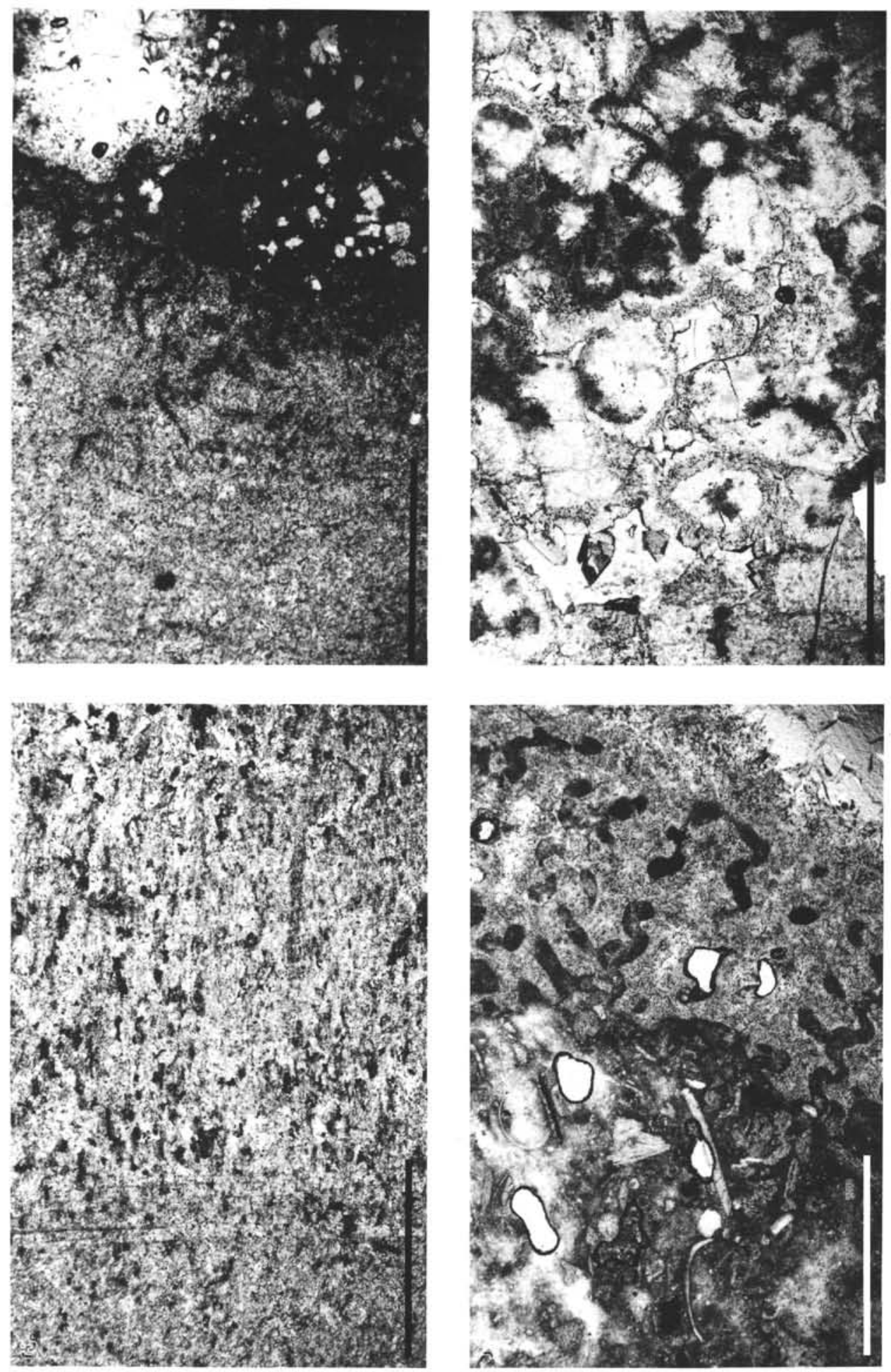

Plate 2. Microfacies and preservational features of megalodontid shell fragments from the lower part of the Rhaetian shallow-water limestone unit, Hole 761C, and from the red dolomitic sponge and tabulozoan/hydrozoan boundstone, Hole 764B. 1. Outer part of a megalodontid shell in contact with host sediment, showing network of sediment-filled microborings. Shell material is replaced by cloudy neomorphic microspar. Note faint relics of growth layering in the shell. In the upper right of the figure are scattered dolomite rhombs. Parallel nicols. Scale bar is $1 \mathrm{~mm}$. Sample $122-761 \mathrm{C}-20 \mathrm{R}-1,22-24 \mathrm{~cm}$. 2. Inclusion-rich bands within neomorphic calcite crystals in the inner part of a Megalodon shell. It is unclear whether these are relics of an alveolar shell structure or diagenetic crystal-growth bands. Parallel nicols. Scale bar is $1 \mathrm{~mm}$. Sample 122-761C-20R-1, 22-24 $\mathrm{cm}$. 3. Mosaic of elongate cloudy neomorphic calcite crystals developed in the outer portion of a Megalodon valve fragment, probably replacing fibrous/prismatic aragonitic shell material. This crystal fabric is vaguely reminiscent of some calcitized botryoidal aragonite cements (e.g., Sandberg, 1985, fig. 4). In the microspar, in the lower part of the figure, relics of growth layering are noticeable. Crossed nicols. Scale bar is 1 $\mathrm{mm}$. Sample 122-761C-22R-1, 5-7 cm. 4. Boring pattern presumably produced an encrusting colony of an uncalcified (ctenostome?) bryozoan, on the surface of a diagenetically altered megalodontid shell fragment. Cloudy neomorphic microspar and clear blocky calcite cement, filling a dissolution cavity, are noticeable in the upper right of the figure. Sediment in the spiral-shaped borings is red fossiliferous microcrystalline dolomite. Parallel nicols. Scale bar is $1 \mathrm{~mm}$. Sample 122-764B-28R-1, 76-78 cm. 